\title{
Crossing the Boundaries of the Home: A Chronotopical Analysis of the Legal Status of Women's Domestic Work
}

\begin{abstract}
Women's domestic work is largely deemed to be a 'labour of love' and lacking any value outside the private family. This reflects an 'ideology of domesticity', whereby women's natural place is deemed to be in an imagined private sphere. In this article, I examine the status of housework in the context of asserting property rights in the home upon relationshipbreakdown. Using Valverde's legal chronotope as a lens, I argue that the ideology of domesticity is not merely present in legal discourse, but also takes on material form through the spatiotemporal ordering of the home. Housework is spatially and temporally concealed behind the powerful veneer of the imagined ideal family home, with corresponding invisibility in the law. For domestic work to be acknowledged, the individual often has to demonstrate that her work transgresses boundaries between private and public. However, as I argue, this transgression is particularly difficult for women, who remain spatiotemporally anchored in the home.
\end{abstract}

\section{Introduction: domestic work and the law}

This article explores the status of women's unpaid domestic work in English law and argues that it is spatially and temporally constructed to reinforce a gendered 'ideology of domesticity'. This ideology is founded on the existence of a public and a private sphere, with women being considered temperamentally suited to the domestic private realm, where their work is materially and metaphorically concealed. The ideology of domesticity is both atavistic and an inaccurate reflection of female lived experience, particularly in its assumption of womanhood as necessarily white and middle-class.

I argue that although domesticity is assumed to belong to an unenlightened past, the ideology remains alive. This is despite measures to introduce formal legal equality in the public sphere, such as outlawing sex discrimination in the workplace. Women's increased participation in economic work has done relatively little to affect the gendered distribution of work in the home (see e.g. Crompton and Lyonette, 2008; Cossman and Fudge, 2002). I set my analysis partly in the context of English property and trusts law, specifically the role of unpaid domestic contributions in seeking to establish a proprietary interest in the home through the common intention constructive trust or proprietary 
estoppel. As I show, the law in this area remains persistently wedded to ideals of domesticity, meaning that women's work is often ignored or sentimentalised in a way that men's work is not.

Employing Valverde's concept of the "legal chronotope" (literally 'timespace') (Valverde, 2015) as a theoretical lens, I argue that domesticity remains so persistent because it assumes material as well as discursive form, with time and space operating as invisible obstacles to women being able to cross spatial and metaphorical boundaries between public and private. Furthermore, the spaces and times of the home are visible within legal discourse, through the apparently common-sense distinctions that are made between different types of domestic work, and the conclusions that the judiciary draw about its motivations and its value. Questions of space and time are frequently overlooked in legal scholarship and are too often assumed to be natural phenomena, fundamentally incapable of challenge (see Grabham and Beynon-Jones, 2019; Blomley, 1998). Subjecting the home to chronotopic analysis, as this article does, provides novel insights into domesticity's pervasiveness and subtlety, exposing the socially constructed nature of that which is often taken for granted.

The article is divided into three parts. First, I analyse the nature of the ideology of domesticity and its historical relationship with legal regulation of women's participation in public life. I argue that, even at its inception in the eighteenth century, domesticity was an illusion and operated to conceal the reality of women's work within the home, particularly that which was performed by marginalised groups. Second, using the lens of the chronotope, I argue that domesticity continues to be reflected on a material level through the spaces and times of the home, which operate to designate the home a feminine space and render women's work in the home largely invisible, while giving visibility and status to typically male work. In the final section, I set the chronotopic analysis in the legal context of disputes over rights in the family home, considering how issues of spatiality and temporality are visible in the property and trusts case law. I argue that work that is spatiotemporally concealed is also likely to be legally invisible and go unrewarded. Despite women's increased presence in the public sphere, they remain stubbornly anchored in the home. 


\section{The ideology of domesticity}

The ideology of domesticity refers to a set of gendered cultural beliefs about women's nature and ideal societal role, which also come to be reflected in dominant legal and political discourses. It originated during the late eighteenth and nineteenth centuries but, as I argue, its past continues to haunt the present, albeit in less explicit forms. Domesticity consists of two core principles. The first is a belief that society is divided into two conceptually distinct spheres; the public and the private (see e.g. Williams, 1991, p. 74). The private sphere is characterised by the heterosexual family, which is presented as the preferable way of organising private life. Second, the ideology asserts that women are ideally suited to the private realm and the activities that take place within the home, including taking primary responsibility for housework and childrearing (Francus, 2012). These activities lose their status as work and instead assume a sentimental or moral character, or a natural expectation of women within heterosexual relationship (Finch and Groves, 1983). While the ideology does recognise men's work on and in the home, the tasks that are viewed as suited to men are distinct to 'women's work'. Men are tasked with 'handyman' work, including repairs, construction, and home improvements (Gorman-Murray, 2014), whereas typical women's work is concentrated within its interior, primarily on ensuring the comfort of its occupants through cleaning, cooking, and doing laundry (see Young, 2005). Thus, even though the ideology recognises that both sexes work within the home, the nature of the tasks assigned to each is different.

\section{The historical development of domesticity}

In the UK, domesticity gained widespread influence during the late eighteenth and nineteenth centuries, particularly during the Victorian era (Folbre, 1991, p. 46). Women were considered unsuited for anything other than domestic work in the home with their province being management of the household and child-rearing. In addition, the ideology imposed idealised standards of behaviour, with women expected to be "modest, chaste, pious, compassionate, and virtuous" (Francus, 2012, p. 2). The home came to represent these qualities. Ideals of womanhood were continuously reinforced through a variety of cultural representations, including art, literature, and magazines (Boardman, 
2000). They also appeared in liberal philosophical writings, including Jean-Jacques Rousseau's theory that women should ideally exhibit passivity and weakness (Rousseau, 1979).

As an ideology, domesticity relied on gendered definitions of space, with the family home transformed from previously being a site of production, into a centre for morality and virtue (Folbre, 1991, p. 464). The beginnings of domesticity also broadly coincided with the Industrial Revolution in the UK and the US, bringing about a transformation in working practices. Production became concentrated in a geographically separate public marketplace, which was seen as the male domain (Fehlbaum, 2016). Women's work in the home was rendered unproductive and their role shifted from worker to passive dependent (Cott, 1997, p. 74). Furthermore, homemaking and childcare came to assume a spiritual dimension, and female identity became spatially anchored in the home. The ideal Victorian woman depicted in art and literature was the 'angel in the house';1 passive, nurturing, and altruistic in her endeavour to create the ideal home for her husband and children (Gregson and Lowe, 1995, p. 226).

Whereas much of the reinforcement of domesticity was cultural, the belief in men's and women's separate role was also mirrored in legal discourse. Women's legal personhood, including the right to vote, was denied until the early part of the twentieth century (Richardson, 2004). Married women, more so than their single counterparts, were restricted from taking part in public or economic life, including owning property separately from their husbands. Blackstone famously remarked that, upon marriage, "the very being or legal existence of the woman is suspended... or at least it is incorporated and consolidated into that of the husband; under whose wing, protection and cover, she performs everything" (Blackstone, 1765, p. 442). In the 1914 case Law Society v Bebb,2 the Court of Appeal infamously rejected the notion that women fell into the category of 'persons' who could qualify and practise as solicitors, motivated partly by the fact that, at the time, married women were unable to

\footnotetext{
1 This term is taken from the title of a poem by Coventry Patmore, in which he praises the virtues of his wife, who he believes symbolises ideal Victorian femininity.

2 Bebb v Law Society [1914] Ch 286
} 
enter into certain binding contracts and would therefore be "unfitted either for entering into articles or for contracting with their clients".3

The early twentieth century saw the start of the removal of formal legal barriers preventing women entering the public sphere, including the passing of the Sex Disqualification (Removal) Act 1919, which provided that "[a] person shall not be disqualified by sex or marriage from the exercise of any public function".4 While domestic work (both paid and unpaid) continued to be seen as a female endeavour, the two world wars led to women entering the workforce in greater numbers than ever before, performing, out of necessity, work that had hitherto been viewed as male (Holloway, 2007, p. 8). However, by the 1950's, there had been a cultural revival of domesticity, with the image of the traditional housewife and mother being promoted heavily through women's magazines and advertising, reinforcing once more women's supposedly natural role within the home (Beaumont, 2017). The traditional housewife took on a public role in the 1950s, being regarded as essential in efforts to rebuild the moral fibre of the country post-war (Beaumont, 2017, p. 147).

During feminism's second wave in the 1960s and 1970s, attention was turned to the plight of the ordinary housewife, whose socially designated role in the home rendered her economically dependent and unable to participate in the workplace (see Oakley, 1974). Large-scale feminist movements such as the Wages for Housework initiative (see Dalla Costa and James, 1973; Federici, 1975) argued for financial compensation for domestic labour and the right for women to work outside the home. The feminist fight was fought on the basis of non-discrimination, leading to ground-breaking legislation being passed in the 1970s to protect against discrimination on the grounds of sex, marital status, or maternity in the form of the Sex Discrimination Act 1975 and the Equal Pay Act 1970. Formal legal barriers to women's liberation from the home had now been removed. In many ways, this seemed to be effective, and the 1980s and beyond saw a significant increase in women's participation in the paid workforce.

3 Ibid, 299 (Phillimore LJ)

4 Sex Disqualification (Removal) Act 1919, s 1 
Tracing domesticity's history is important in terms of understanding its continued influence today. The domesticity of the Victorian era and of the 1950s tends to be looked back upon as a backward time that has been left behind to make way for an enlightened and progressive future where women's concerns have 'moved on' from questions of distribution of domestic work. Indeed, there is relatively little modern feminist scholarship dealing specifically with the question of housework (as distinct from care) and the home as the locus for female oppression. There has also been a shift in the scale of study within feminist socio-legal scholarship. Valverde (2015) argues that today's scholars are turning their focus away from the household, towards a more expansive perspective, seeing the status and distribution of socially reproductive work predominantly as a global issue; evidenced for instance in Hochschild's concept of "global care chains" (Hochschild, 2001). My position is that, while the global perspective is a vital one in terms of understanding the flows of power involved in socially reproductive labour, the household also remains relevant as a site of study. Increased female participation in the workplace has not solved past problems; it has merely masked them and rendered them more complex. For despite the shift in women's working patterns, the gendered distribution of unpaid socially reproductive labour in the home has remained relatively intact, with women still performing the vast bulk of care and housework, especially daily repetitive tasks such as cooking, cleaning, and laundry.5

\section{The utility and illusions of domesticity}

Domesticity is more than a set of culturally and historically entrenched biases. Organising society into separate spheres and concealing the work that takes place behind the façade of the ideal home is of significant economic benefit both to men as a class, and to the state. Men are relieved of the burden of managing the home or caring for children, leaving them relatively unencumbered to pursue economic endeavours in the public sphere (Himmelweit, 1995). The state draws considerable advantages from perpetuating domesticity's division between the public and private. By privatising and sentimentalising work that takes place in the home, such as childrearing and caring for an increasingly

\footnotetext{
5 See Office for National Statistics Women Shoulder the Responsibility of 'Unpaid Work' 10 November 2016 , which shows that women perform on average $60 \%$ more unpaid domestic work than men. https://www.ons.gov.uk/employmentandlabourmarket/peopleinwork/earningsandworkinghours/articles/womens houldertheresponsibilityofunpaidwork/2016-11-10 (accessed 31 March 2019)
} 
elderly population, state responsibility for its provision is limited. Not only does domesticity ensure that domestic work remains largely unremunerated, but it also ensures a class of willing workers by teaching women from birth that their destiny lies in taking care of the home and family. Women are told that their status as a 'good mother' or 'good wife' depends on them performing unpaid work. The state therefore has a significant vested interest in sentimentalising domestic work, rendering it a natural part of womanhood rather than unpaid and uncounted labour that allows the remainder of society to function efficiently.

Domesticity, based on a notion of an 'essence of femininity' has always claimed to speak for all women (Davidoff and Hall, 2013). In deconstructing it, it is therefore easy to focus only on how it adversely affects women as a class. However, this overlooks the more nuanced classed and racialised divisions that are perpetuated by the ideology, issues that are increasingly relevant within modern British society, where claims of equality of the sexes are frequently made based on women's presence in the workplace. Yet, it is clear that women's increased participation in paid work is not a result of men's assumption of domestic responsibilities. Instead, some women (predominantly white and middle-class) can gain status in the public realm, but this is often as the direct result of outsourcing domestic burdens to other women, something that poorer or more marginalised women are unable to do.

The role of outsourcing is important in terms of highlighting the illusory nature of domesticity. While the ideology imbues women's work in the home with a moral and emotional quality and strips it of any economic or productive value, it simultaneously recognises that certain tasks can be delegated to others in return for money and that women can maintain the performance of domesticity even if they do not carry out all the work themselves. This is possible because domesticity is ultimately about a 'finished product' (the ideal home and contented family), without acknowledgment of the labour involved in producing it. Roberts has argued that domestic work is grouped into categories of "spiritual" and "menial" work, which "enables many professional women to go to work without disturbing the sexual division of housework or relinquishing their role as spiritual housekeepers" (Roberts, 1997, p. 57). Responsibility for the upbringing of children (but not necessarily performing 
all of the caregiving work) is given higher status and visibility than the day-to-day labour involved in keeping the house clean (Roberts, 1997). This illustrates that domesticity has always been a white, middle-class ideal, made possible for socially privileged women through the unacknowledged and hidden labour of more marginalised women. Even during the early days of the ideology, many women's lives bore no resemblance to the ideal (Francus, 2012, p5). Only affluent women could fully embody and thus perpetuate domesticity. To do so, they employed women to work as domestic servants, whose labour behind the scenes carrying out manual, dirty, and time-consuming tasks gave respite to the 'lady of the house' and allowed her to assume the role of the tranquil and contented housewife and mother. In the UK, these domestic servants came from the poor working classes, and in the US (where domesticity was similarly prevalent during the eighteenth and nineteenth centuries) they were often women of colour (Staples, 2007; Holloway, 2007).

The racial and classed underbelly of domesticity is particularly relevant to a modern analysis of housework, as it sharply illustrates how women's relationship to housework has been rendered increasingly complex and concealed. Women's participation in the economic sphere is offered as proof of gender equality (see e.g. McRobbie, 2007). Yet, the expectation for women to oversee the household has not disappeared. Instead, as has always been the case, domestic harmony is partly made possible by the invisible work of other women. As Gregson and Lowe's research found, women's increased numbers in the paid labour market coincided with a revival of middle-class outsourcing of domestic work, such as employing nannies or cleaners, often from immigrant backgrounds (Gregson and Lowe, 2005, p. 3). The concept of domestic service reveals a contradiction within the ideology, for it involves some women having to work and thus sacrifice their own domesticity. Yet, although they are engaged in paid work, working within someone else's home brings none of the status that work in the public sphere does (see e.g. Hondagneu-Sotelo, 2007).

Efforts to achieve equality have predominantly focused on opening the economic sphere to women. While this has had some positive effect in terms of reducing female dependence on men, it has not led to domestic work being shared equally between the sexes. Domesticity cannot simply be dismissed as belonging to an unenlightened past from which we have now moved on. Its essence remains ingrained 
in societal and legal consciousness. It is still thought so natural that it is almost incapable of being challenged. If anything, the removal of barriers between the spheres has led to the argument that women are choosing to do the lion's share of housework and care (see Fineman, 2013, p. 19). In the next section, I argue that part of the reason that domesticity is so difficult to escape is that is repeatedly reiterated and reinforced through the spatiotemporal organisation of the home, which promotes gendered separation of household tasks and which imagines the home as an essentially feminine space. This ensures that domestic work, and particularly that which is performed by women, remains spatiotemporally hidden from view, allowing it to go unnoticed, unappreciated, and unrewarded.

\section{Reinforcement of domesticity through space and time}

In this section, I draw on Valverde's concept of the legal chronotope to analyse how spatial and temporal factors interact to reinforce domesticity to the extent that it is considered natural and incapable of challenge. Valverde has adopted the chronotope from the Russian literary critic, Mikhail Bakhtin, who described it as "the intrinsic connectedness of spatial and temporal relationships that are artistically expressed in literature" (Bakhtin, 1981, p. 84). The chronotope is an analytical tool of literary critique, illuminating how authors infuse measures of time with space as a storytelling device, with certain chronotopes denoting a particular literary genre, and functioning as the "organising centres for the fundamental narrative events of the novel" (Bakhtin, 1981, p. 250). For critical legal scholars, the chronotope also has an analytical function. By paying attention to questions of time and space, the chronotope enables us to see that "different legal processes are shaped and given meaning by particular spacetimes" (Valverde, 2015, p. 11) and, as argued in this article, that norms and ideologies are transmitted through spatial and temporal organisation. Chronotopical analysis offers the potential of novel and radical insights, particularly as both space and time are often seen as natural phenomena rather than being socially constructed in order to reinforce particular values and messages (Blomley, 2005; Mawani, 2014).

The home as a chronotope 
Here, I conceptualise as a powerful combination of spatial and temporal features that upholds and reinforces domesticity. As it is imagined in culture, society, policy-making, and law (as a place where the law does not generally intrude), the home serves as a physical boundary between the public and private spheres (Blomley, 2005, p. 281). It is considered quite literally "detached" (Valverde, 2015, p. 19) from the public sphere, which serves as a symbol of the economic self-sufficiency of the family unit, and marks the spatial limits to which the state can intrude into private life. Notably, those who fail to conform to the autonomous ideal of financial autonomy often find themselves occupying structures that are more scrutinised and less detached, such as purpose-built social housing, hostel accommodation, or even public spaces such as streets or parks. Furthermore, and reflecting the ideology of domesticity and its gendered separate spheres, the home is predominantly imagined as a feminine space, a point of safety, intimacy, and nurture; often used to contrast with the unsafe, cold, and harsh public sphere of the street, or the workplace. This depiction takes place both through language and visual spatial representation, seen in the way that "the imagery and vocabulary that feminize [the home] is subtly ubiquitous in the images of enclosure, protection, and warmth that connote both the womb and the vagina in a masculine imagination of enclosing, safety, security, and dreamy warmth" (Price, 2002, p. 49).

Nonetheless, despite its status as a refuge from public scrutiny, the home is "redolent with social meaning" (Madigan and Munro, 1991, p. 120). It is a symbol to the outside world, displaying social status and conformity (or lack of) with expectations around the organisation of private life. Significant social and cultural pressures exist to ensure that the home conforms to its imagined ideal, both internally and externally. The construction and geographical placing of the home involves powerful reinforcement of norms and ideologies. Although the home is idealised as a place of self-expression and a reflection of personal identity, much of this is pre-determined for its occupiers based on what they are thought to desire. This is especially so in the UK, where spatial constraints mean that very few people design and construct their own homes according to personal specifications. Instead, builders and architects design structures according to "the successful identification of "what people want" (Chapman and Hockey, 1999, p. 5). This inevtiably involves various value judgments and 
assumptions about who the imagined occupants will be, and how they will organise their domestic life.

Geographical zoning of houses, including the division between residential and urban areas, reflects ideals of domesticity. The family home is depicted as a safe haven, usually some geographical distance away from the potential dangers of the urban public sphere. The development of suburbs in nineteenth and twentieth century Britain helped to designate these as the ideal setting for middle-class life. The suburbs also reflected gendered assumptions about the organisation of family life, notably that women would stay at home to care for their children and required a safe and suitable space in which to do so (Day, 2000, p. 109). Residential settlements such as Garden Cities were promoted as "providing a healthy and morally superior environment for women and children, segregated from the overcrowding and corruption of the city" (Madigan and Munro, 1999, p. 61), and embodying “individual domesticity and group monitored respectability" (Thompson, 1982, p. 8).

The home's ideological force derives not merely from its spatial layout and geographical positioning, but also from the temporalities that constitute it. As Bakhtin said of chronotopical analysis, "time, as it were, thickens, takes on flesh, becomes artistically visible, likewise space becomes charged and responsive to the movement of time, plot and history" (Bakhtin, 1981, p. 84). The 'flesh' to the spatially constituted ideal home comes from the equally idealised temporal framework of "the life course" (Valverde, 2015, p. 20), which is expected to be played out in the home's space. The life course is a set of apparently defining 'life events' that an individual is expected to undertake, including childhood, leaving home, employment, partnering, marriage, childrearing, and retirement. This life-course is "chrononormative" (Freeman, 2011), operating to reinforce a cultural and societal ideal (white, middle-class, and heterosexual). It does not merely set expectations for the various life events, but also imposes a vision of the 'right' time in life for these (Riach et al., 2014). The life course operates in tandem with the home as a spatial location because the ideal home is always imagined with an ideal occupant in mind (Valverde, 2015, p. 20). The architect's assumptions about 'what people want' discussed above, are invariably shaped by chrononormative assumptions of who 'people' are considered to encompass. 


\section{Invisible work: The spatiotemporal distinctions between male and female work}

Dominant liberal conceptions of home tend to emphasise home as a source of stability and permanence, a point of constancy in an increasingly precarious and threatening world (Saunders, 1984; Saunders and Williams, 1988). Home is imagined as an anchor, both spatially and psychologically, a point to which the individual can always return throughout her lifetime, simultaneously reflecting the supposedly feminine virtues of nurture and comfort (Dupuis and Thorns, 1998, p. 30). The home's ideal occupant; the married family, is also discursively framed in terms of its stability, of benefit both for individual family members and on a broader societal level (Rowthorn, 2002). However, this conception of home as a fixed and stable entity ignores constant the work involved in making it; a task that is never fully completed. The reality of the home is a spatiotemporality that is in a constant state of flux, "iterative, always in the making, unstable and endlessly deferred" (Waitt and Gorman-Murray, 2011, p. 1381). To assert its symbolic power, the home requires constant performativity and action; spatial arrangements and temporal working rituals that normalise gendered roles (Bowlby et al., 1997, p. 346). As I show in this section, some of these are more visible than others.

Housework is spatiotemporally configured to uphold an idealised image of family life. Domesticity, constituting the ideal family and the ideal home, operates as a façade that conceals the reality of women's daily housework routines. While public life and the working day is governed by a linear and clearly defined 'clock-time', and productivity is measured in hours, time spent on domestic work is much less visible and often incapable of accurate measurement (Daly and Cobb, 1994, p. 458). The temporality of housework is fluid, often fragmented, and frequently interrupted. Like grains of sand, the temporality of domestic labour is expected to flow around the more solid structures of the clockmeasured working day, often obscured by the more temporally visible activities of other family members. It is frequently performed at 'invisible times'; while other family members are absent from the home, or after they have gone to bed. Furthermore, it is often carried out subconsciously (Bakker, 2007, p. 543), or overlooked by workers themselves because it forms part of more visible activities such as spending time with family members (Roberts, 1997). Relying solely on clock-time as a frame 
of reference for domestic work is likely to significantly downplay the extent to which it dominates women's lives, not merely in the sense of hours spent on a task, but also the never-ending responsibility for managing and supervising the household (see Everingham, 2002, p. 342).

The invisibility of domestic time combines with the home's layout, which is constructed to hide certain types of domestic work, while rendering others more visible. Unpleasant and time-consuming work is concealed from from public view, allowing the façade of domesticity to continue. Madigan and Munroe have argued that:

It is the front of the house which displays the socio-economic status of the household, while the back has a more utilitarian design, often in cheaper materials, which reflects the demands of domestic labour (wash houses, bin shelters, trades entrance etc) (Madigan and Munro, 1991, p. 121).

Thus, the dominance of domesticity means that women's work becomes consigned to the shadows lest it disrupt the illusion of the ideal home as a site of rejuvenation and as a status symbol that represents the ideal family. Historically, this spatial construction of the home also had considerable racialised and classed aspects, as it hid the existence of paid domestic workers, through servants' sleeping quarters and entrances that were not visible from the front of the house. The presence of this work or of those who performed it would have disrupted the illusion of domesticity and the status of the home as unproductive and sentimental.

By contrast, the domestic work that is typically seen as 'male' by the ideology of domesticity, such as construction, outdoor maintenance, and DIY tends to be spatiotemporally different from that labelled as women's work. Men's work tends to be (although is not always) less time-essential than women's, meaning that it can be more easily combined with paid work and thus does not create the same tension between public and private (Silbaugh, 1996, p. 12). Additionally, rather than requiring constant repetition, men's work usually has a discernible start and end point. Whereas cleaning and tidying the house typically has to be performed daily to some extent, painting the exterior of the house or building an extension both have a sense of being capable of being 'complete'.

Spatially, male work can also be said to have greater public visibility and impact. Construction is understood as making a mark on the world in a way that housework is unable to do. Whereas 
housework preserves and restores the home to an acceptable standard, construction effects change, visually transforming what is there, rather than simply maintaining the status quo of the home (Young, 2005, p. 4). It demands visibility; it is admired and valued for enhancing the home's desirability, hinting at social status and adherence to societal norms. This distinction furthermore supports Young's observation that "women serve, nurture and maintain so that the bodies and souls of men and children gain confidence and extensive subjectivity to make their mark on the world" (Young, 2005, p. 1). Women's domestic work is essential for society to function effectively, yet its spatiotemporal concealment means that it is never fully rewarded or even noticed.

\section{A foot in each realm: Navigating the boundaries between the private and public}

This spatiotemporal ordering of housework as distinctly separate to, and incompatible with, paid work can cause difficulties for women in terms of traversing physical and metaphorical divides between the public and the private sphere. This is something that has arguably intensified in conjunction with women's increased presence in the paid workforce. Despite retaining primary responsibility for daily housework, the state now also expects women to be economically productive (McKie et al., 2002, p. 899). However, the fact that their work in the home lacks visibility means that tensions between the public and the private in women's lives is often overlooked or downplayed in public policy. As McKie et al have argued, "social and employment policies appear to presume a seamless shift from home to work" (McKie et al., 2002, p. 898). State policies fail to account for the difficulties that women experience in having to cross the spatial and temporal boundaries between home and the workplace and the expectations on them to be in two places at the same time.

The frequently fixed spatial and temporal nature of paid work requires women's obligations in the home to be moulded around the working day. Often this has the effect of restricting both the geographical zone and the hours that women can work, unless they can delegate their responsibilities to other women. Because paid work is predominantly measured in terms of adherence to clock-time and often requires the worker's physical presence in the workplace, obligations in the home are barriers to women conforming to employment expectations, because these assume an ease of transition between the public and private spatiotemporalities. Even in a new era of shifting forms of 
labour such as increased home-working, and zero-hours contracts that potentially challenge the existence of a spatially separate workplace, these modern working patterns also create restrictions for women in their assumption that the typical worker is unburdened by domestic obligations. Remarking that modern-day working is increasingly built around an image of innovation and entrepreneurship, Amoore argues that "[i]f worker-entrepreneurs are to 'embrace uncertainty' in their working lives, their working time becomes less predictable, their time for domestic and care work diminishes" (Amoore, 2004, p.189). Even flexible and home-working practices have not shifted the fundamental assumption that work and home-life belong in separate realms. Women are required to straddle the two, leaving them metaphorically standing with one foot in each sphere, each constantly threatening to spill over and disrupt the other (see McKie et al., 2002, p. 913). A semblance of balance between the two spheres may be achieved for the middle-class women who are able to purchase the labour of less privileged women, but this provides only an illusory solution to the problem, as it is premised on the exploitation of working-class and immigrant women (see Anderson, 2000). It also places additional burdens in the form of physical stress and lack of leisure-time on those women who are tasked with performing domesticity for others while simultaneously needing to look after their own family and home (Williams, 2010).

The purpose of this section was to explore how domesticity is reproduced through the spatiotemporal ordering of the home, as well as through the gendered performance of domestic work. The chronotopical lens illuminates how the spaces and times of the home operate to render women's work largely invisible. By regarding domestic work in spatiotemporal terms, it has also been possible to see the distinction between men's and women's work, which upholds the ideology of domesticity and the belief that men and women have distinct roles and distinct areas of spatial belonging. It is this which forms the basis of my analysis in the final section, where I turn to the context of property rights in the home, exploring the ways in which the home and housework chronotope is visible in judicial deliberations over the value (or lack of) of domestic contributions and the ways in which judges make distinctions about men's and women's work that betray a continuing adherence to the ideology of domesticity. 


\section{The chronotope in law}

One of the few instances where domestic work does gain legal attention is in the context of property law disputes between unmarried cohabitants, where contributions in the form of domestic labour can be used to support an assertion of an interest in the home under a common intention constructive trust, or under the doctrine of proprietary estoppel. As I show, an analysis of the case law reveals a hierarchy of perceived value of unpaid work. Work that is conceptually and spatiotemporally removed from the home, such as helping in a family business, or that is typically 'men's work', such as building or construction, is more likely to lead to a share in the home than ordinary housework. Additionally, when tasked with interpreting the motivations for women's domestic contributions, judges remain heavily influenced by the chronotopic combination of the family home and the heteronormative life-course in a way that they do not when analysing men's work.

The legal context: constructive trust and proprietary estoppel

In the absence of specific legislative provision for unmarried cohabitants in English law, any disputes between them regarding the question of proprietary rights in the family home fall to be dealt with under ordinary property and trusts law, through the common intention constructive trust or the doctrine of proprietary estoppel. A constructive trust can arise either where the couple jointly own their home or where legal title is held by just one of them. It requires evidence of a common intention that the parties intended to share the beneficial ownership of the home. 6 The position is relatively straightforward where legal title is jointly held (but where there is disagreement as to the size of the parties' respective beneficial shares). Here, Stack $v$ Dowden 7 and the subsequent Jones $v$ Kernotts has established that there is a strong presumption that the parties also intended to hold the beneficial interest in equal shares. This presumption can be rebutted by evidence that the parties held a contrary intention, but, as Stack itself confirmed, unequal financial contributions (such as where one party is the breadwinner and the other is the homemaker) do not by themselves suggest that unequal shares

\footnotetext{
6 Lloyds Bank v Rosset [1991] 1 AC 107

7 Stack v Dowden [2007] UKHL 17

8 Jones v Kernott [2011] UKSC 53
} 
were necessarily intended.9 While the performance of unpaid work by one party may assist the court in ascertaining intention, it is of greater relevance where legal title to the home is held by just one party.

In sole ownership cases, domestic work has relevance in two situations. The first is where the parties have had express discussions regarding ownership of the home and the owner has made some form of representation that beneficial ownership will be shared.10 In order for a constructive trust to be established, the claimant must also show that she has relied on these discussions to her detriment. Detriment can include the performance of unpaid work in the home, the important point being that it must be evidenced that but-for the discussions surrounding ownership, the work would not have been performed.11 The second scenario is where there is no evidence of express discussions but the parties have behaved in such a manner that the court can infer that they intended to share the beneficial ownership of the home from their conduct. In the highest authority on sole ownership, Lloyds Bank $v$ Rosset,12 domestic contributions were expressly discounted as by themselves providing evidence of an intention to share ownership, with only direct financial contributions to the deposit or mortgage being thought sufficient. However, since Rosset, there have been obiter suggestions that the test is no longer as strict and that the court must instead consider the whole course of the parties' relationship when determining whether intention can be inferred.13 Therefore, uncertainty remains (Sloan, 2015), but if a more generous approach is correct, domestic work could be relevant in terms of showing evidence of a sharing intention.

The doctrine of proprietary estoppel has significant overlaps with the constructive trust. It permits the court to award a remedy where the defendant owner has made a representation to the claimant that the latter is to be given rights in respect of the home.14 In contrast to the constructive trust, it does not require evidence that the defendant promised the claimant an immediate interest. Instead, the representation could conceivably relate to future rights, including a promise to make provision by way

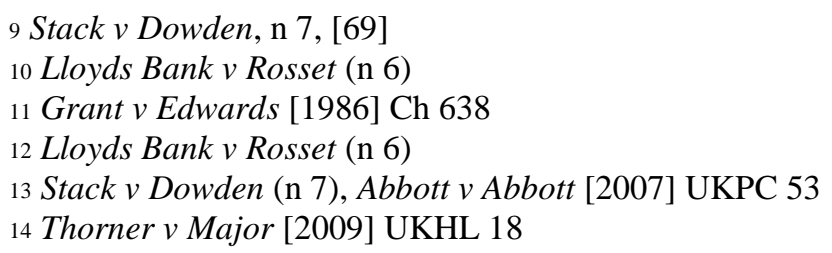


of a will to take effect on death.15 As well as showing evidence that an assurance was made, the claimant must show that she relied on this to her detriment in some way. In estoppel cases, it is therefore at the point of proving detrimental reliance that domestic work performed in reliance on a promise of a proprietary interest has potential relevance.

\section{Spatiotemporal influences in legal reasoning}

The claim that the judicial treatment of domestic contributions is heavily gendered is not a novel one. For instance, Flynn and Lawson have remarked that female claimants usually have to show that their unpaid work was "extraordinary" in a way that male claimants do not, betraying judicial attitudes that women are naturally suited to the domestic realm (Flynn and Lawson, 1995, p. 117). Wong has also argued that the judiciary adheres to "a legal family ideology where domestic tasks are seen as a 'labour of love' performed by women" (Wong, 2007, p. 274). Here, the chronotopical lens offers an expansion and deepening of the existing feminist critique, illuminating not only the judiciary's gendered interpretations of domestic work, but also the way that the spatial and temporal ordering of this work comes to influence the way it is perceived and valued and how women are disadvantaged even if they perform typically 'male' work. I argue that women's work can only be considered extraordinary if it falls outside spatiotemporal expectations imposed by the ideology of domesticity. That is, it must not only transcend the boundaries of what is considered female work (i.e. ordinary housework) but, more importantly, it must be imagined as going beyond women's relational role under the ideology of domesticity, which is reinforced by the notion of the chrononormative lifecourse. An analysis of the cases suggests that work that is spatiotemporally visible is more likely to be given legal visibility and value than that which is hidden, meaning that women who perform 'men's work' are more likely to be able to show an intention of ownership of the home. However, as I show, women's association with domesticity is so strong that even where their work may be spatiotemporally 'out of the ordinary', this often proves insufficient to displace the presumption that they are motivated primarily by love and affection.

15 Re Basham [1986] 1 WLR 1498 
Within the case law, there are clear distinctions made based on the nature of the work in question. Although she is writing from a US and Canadian perspective, Philipps' observation that unpaid work with an economic association, thus crossing the divide from the private to the public sphere, is more likely to justify a finding of proprietary rights than ordinary housework (Philipps, 2008, p. 82), is also evident in English case law. The courts have readily recognised that unpaid work in a family business, for example a farm, can constitute detrimental reliance for the purposes of establishing a constructive trust or proprietary estoppel.16 Additionally, it has been acknowledged that the performance of construction work can justify an inference that the parties intended to share the beneficial ownership of the home.17 On the other hand, ordinary housework tends to be regarded as an incidental part of cohabitation, or an expression of affection, and therefore insufficient to justify an interest in the home. This was seen in Thomson $v$ Humphrey, 18 where the claimant sought to rely on regular housekeeping and cleaning. Warren $\mathrm{J}$ explained that "there was nothing out of the ordinary in what she did and nothing that can lead, anyway, to the acquisition or ownership of a share in a property." 19 This statement reinforces the expectation that housework, a traditionally female endeavour according to the ideology of domesticity, requires something 'extra' in order to justify a beneficial share in the home. The traditionally male domain of construction on the other hand, does not appear to carry the same requirement of extraordinariness.

Classical theories of property recognise the notion of awarding property rights based on the performance of labour (Harris, 1999). For instance, Locke's theory employed the concept of "labourmixing" on the basis that a person's physical labour is seen as becoming mixed with the land's physical structures, thereby justifying legal recognition (Locke, 1689/1978, p. 18). However, the decision as to what type of labour justifies reward is inevitably tied to social conventions and beliefs as to what work is considered meritorious and valuable (Harris, 1999, p. 431). In English property law, the determination of whose labour merits reward has always been gendered, racialised, and classed and based around a white and male model of ownership (see Keenan, 2017). It has been

16 Thorner v Major (n 14), Hammond v Mitchell [1991] 1 WLR 1127

17 Stack v Dowden (n 7)

18 Thomson v Humphrey [2009] EWHC (Ch) 3576

19 Ibid. [45] (emphasis added) 
established that preservation and maintenance do not have a sufficiently direct connection to the property to warrant an inference that it was intended that the claimant should have a share.20 Conversely, construction work, which changes the geographical landscape, as well as providing "a rupture in the continuity of history" (Young, 2005, p. 27), appears to provide a more obvious link to ownership than mere preservation, even when the latter is performed over a number of years. Law's preference for work that makes a spatial change can be seen in Baroness Hale's comments in Stack where she describes the situation "where one party has financed (or constructed himself) an extension or substantial improvement to the property, so that what they have now is significantly different from what they had then".21Housework on the other hand merely preserves what is already there. The distinction between the two is presented as logical and common-sense, yet it betrays a heavily gendered view of what constitutes work and what justifies ownership.

In order for domestic work to gain legal status, it must demonstrate that it breaks free of the material and metaphorical boundaries imposed by the ideology of domesticity. As discussed in the previous section, domesticity is reinforced through the home's spatiotemporal ordering, emphasising the point that 'it is not simply that household labour is designated as 'women's work' but that for a woman to engage in it and a man not to engage in it is to draw on and exhibit the 'essential nature' of each" (West and Zimmerman, 1987, p. 30). In Lloyds Bank v Rosset, the claimant relied on domestic work in the form of painting and interior decoration of the home, work that could be said to fall under domesticity's expectations of women to 'make the home' (see Darke, 1994; Madigan et al., 1990). Mrs Rosset's work was spatiotemporally located so as to reinforce its sense of belonging in the private realm, away from legal scrutiny. She occupied the home's interior, ideologically designated as the female domain. Additionally, her work was performed against the temporal backdrop of heterosexual marriage, with its expectations of permanence, of building a joint future, making the ideal home and conforming to the ideal life course. Mrs Rosset was thus located in her expected place and was performing her expected role. Her work was unable to transgress the boundaries of domesticity in order to enter the legal realm. Drawing on imagined comparators of "most housewives"

20 See Burns v Burns [1984] Ch 317

${ }_{21}$ Stack $v$ Dowden (n 7), [70] (emphasis added) 
and "the average housewife", Lord Bridge was able to dismiss the contribution with the famous statement that

It would seem the most natural thing in the world for any wife, in the absence of her husband abroad, to spend all the time she could spare and to employ any skills she might have, such as the ability to decorate a room, in doing all she could to accelerate the progress of the work quite irrespective of any expectation she might have of enjoying a beneficial interest in the property 22

Lord Bridge instantly separated Mrs Rosset's work from the legal question of property rights by appealing to gendered expectations in the home. He also reinforced the sense that the private sphere is characterised by altruism rather than self-interested behaviour. By performing her expected role, both in terms of her work and its spatiotemporal setting, Mrs Rosset was denied a remedy.

The position of Janet Eves, the plaintiff in Eves $v$ Eves,23 was different. She was not married; indeed, she was referred to in the headnote as a "mistress", with its connotations of a clandestine, precarious, and above all socially unacceptable relationship, contravening the morality of domestic ideology. Spatially too, her work was located in a different zone to that of Mrs Rosset and fell outside the boundaries of what was expected of her. She "broke up concrete" and "demolished a shed and put up a new shed".24 Much of her work took place outside, was publicly visible, and substantially changed the nature of the home rather than merely preserving it. She was awarded a share in the home because, in the words of Lord Denning, "she did much more than many wives would do".25 Here, although speaking as if there was a consensus on what wives do, Lord Denning was measuring Janet Eves against a socially constructed ideal of domesticity. She had gone further than what she was expected to do as part of her wifely role and could therefore be rewarded with a share in the home.

That is not to say that it is always sufficient for female claimants to demonstrate that their work exceeds what is expected of them. The case law shows that the home chronotope, namely the combination of the spatial setting of the home and the chrononormative temporal measure of a heterosexual marriage-like relationship, operates as a powerful obstacle to the claimant establishing

22 Lloyds Bank v Rosset (n 6), p131

23 Eves $v$ Eves [1975] 1 WLR 1338

24 Ibid., p 1340

25 Ibid., p 1340 
that domestic contributions were motivated by an expectation of financial gain. For instance, in James $v$ Thomas,26 the claimant "drove a tipper, dug trenches, picked up materials, laid concrete, tarmac and gravel".27 Her work went beyond mere housework, yet was held to be insufficiently connected to the question of property rights in the home. As Sir John Chadwick reasoned:

She worked in the business and contributed her labour to the improvements to the property because she and Mr Thomas were making their life together as man and wife. The cottage was their home: the business was their livelihood. It is a mistake to think that the motives which lead parties in such a relationship to act as they do are necessarily attributable to pecuniary self-interest.28

Sir John Chadwick's comments words reflect the core elements of the ideology of domesticity and its belief in separate spheres. A conceptual distinction is made between the intimate relationship (where there is an expectation of female altruism) and selfish, market-based behaviour that reflects "pecuniary self-interest". There is very much a sense that Ms James cannot be motivated by both: a choice must be made between domesticity and self-interest.

A comparison of the contrasting approaches in reasoning by the same judge, HHJ Paul Matthews, in two recent cases illuminates the distinction in perception between male and female claimants relying on contributions in the form of unpaid work. In Dobson $v$ Griffey, 29 a case involving a female claimant who had undertaken significant renovation work of the property in question, HHJ Matthews acknowledged that "there can be no doubt that the claimant did a great deal of laborious work".30 However, drawing on the home chronotope, he reasoned that "her labour and commitment were understandable in the context of [the parties'] relationship and their intended long-term future together with children. This was to be her home... It is unnecessary to suppose some quasi-commercial bargain between them to explain it." ${ }_{11}$ Once more, this reflects a perceived incompatibility between the private and the public that characterises the ideology of domesticity. HHJ Matthews assumed that because the work took place in the context of the idealised heteronormative life course (e.g. a long-

\footnotetext{
26 James $v$ Thomas [2007] EWCA Civ 1212

27 Ibid., [4]

28 Ibid., [36]

29 Dobson v Griffey [2018] EWHC (Ch) 1117

30 Ibid. [76]

31 Ibid., [84]
} 
term married or quasi-married future and the expectation of children) and within the idealised and feminised space of the home, it could not also carry an expectation of a financial interest.

By contrast, his reasoning in Culliford $v$ Thorpe 32 shows willingness to attribute commercial motivations to unpaid work performed by a male claimant in a relational context falling outside the heterosexual ideal. The claimant, Jocelyn Thorpe was in a long-term partnership with Rodney Culliford, who died in 2016. The appeal concerned Mr Thorpe's claim for a declaration of trust and/or proprietary estoppel in respect of the home. In support of his claim, Mr Thorpe relied on the fact that he had carried out a significant amount of unpaid work in the home, including repairing the boiler and decorating the main bedroom. He said that he had done this in reliance on a conversation that he had with the deceased in 2012, when the latter spoke words to the effect of "what is mine is yours and what it yours is mine". 33 HHJ Paul Matthews found that "the defendant would not have done the work he did if there had not been an agreement of this kind between them".34 Thus, the agreement (which consisted of a casual conversation when the parties were moving house) was given significant force through the use of contractual analogy. HHJ Matthews stressed that the court was "implementing the agreement- the informal bargain- between them." 35 In contrast to his approach in Dobson (where the parties had also talked informally about ownership), the parties' casual conversation was stripped of its emotional and domestic context and treated similarly to an arms-length transaction.

While male claimants can find it easier to convince the courts that their motivations for domestic work were financial rather than affectionate in nature, this may require their work to be removed from the timespace of the home and situated within an imagined marketplace, where rational actors bargain for rights. In Wayling $v$ Jones, 36 the plaintiff had cared for his male partner until the latter's death, including working unpaid in a hotel business. The deceased had on various occasions promised the plaintiff that he would inherit from him; a promise that was ultimately never fulfilled. The court's commercial approach was notable. The plaintiff was described by the trial judge as being "in [his

\footnotetext{
32 Culliford \& Anotherv Thorpe [2018] EWHC (Ch) 426

33 Ibid., [26]

34 Ibid. [32]

35 Ibid. [78]

36 Wayling v Jones [1995] 69 P \& CR 170
} 
partner's] service" and was referred to by the Court of Appeal as "his chauffeur", painting him very much in the light of an employee rather than an intimate partner (Flynn and Lawson, 1995, p. 116). In order for his domestic work to be valuable, the claimant had to be symbolically separated from the powerful home chronotope. Additionally, the court in Wayling chose to lay particular emphasis on the aspects of work that were spatially separate from the home (e.g. his work in the hotels and as a driver), as well as recharacterising the relationship as one of employer and employee, one that belongs firmly in the public sphere.

That men's work is more readily categorised as commercial suggests that men's ideological tie to the home is not so profound as women's. Furthermore, it reflects the material reality of the spatiotemporal divisions between home and work. Men are naturally expected to inhabit the public sphere and they find the spatial and temporal traverse between the two easier than what it is for women, both in real terms, through navigating the boundaries between home and work, and in a metaphorical sense, in the way that their conduct and motivations are interpreted by the judiciary.

\section{Conclusion}

In this article, I was concerned not only with how the law's relationship with domestic work betrays adherence to an ideology of domesticity in the context of English property law, but also how this ideology manifests itself on a material level and the extent to which this materiality is in turn reflected in the case law. Although domesticity is often dismissed as belonging to a backward past, from which significant progress has been made, its prescription of gendered roles within the home appears to persist.

Using the spatiotemporal combination of the chronotope as an analytical tool enabled illumination and challenge of boundaries and binaries that have over time been rendered normal and common sense. By viewing the home as a chronotope, the differing levels of visibility of domestic work were highlighted. Work that is typically performed by men has a stronger link to the outside world and the public realm. So-called women's work, comprising the daily routines of housework is more likely to be obscured behind the façade of the ideal home, both on a spatial and a temporal level. In turn, the 
spatiotemporal constitution of domestic work comes to be reflected in case law that deals with the question of ownership rights in the family home. Furthermore, judges appear to be influenced by images of domesticity and its gendered division of work in the home. Women's work, even if it manages to transcend the boundaries imposed by domesticity, is restricted by a persistent assumption that it is primarily motivated by affection and wanting to create the ideal home and the ideal heteronormative relationship.

\section{$\underline{\text { References }}$}

Amoore L (2004) Risk, Reward and Discipline at Work. Economy and Society 33, 174-196.

Anderson B (2000) Doing the Dirty Work. London: Zed Press.

Bakhtin M (1981) The Dialogic Imagination: Four Essays. Austin: University of Texas Press.

Bakker I (2007) Social Reproduction and the Constitution of a Gendered Political Economy New Political Economy 12, 541-556.

Beaumont C (2017) What do Women Want? Housewives' Associations, Activism and Changing Representations of Women in the 1950s. Women's History Review 26, 147-162.

Blackstone W (1765) Commentaries on the Laws of England. Oxford: Clarendon Press.

Blomley N (1998) Landscapes of Property. Law \& Society Review 32, 567-612.

Blomley N (2005) Flowers in the Bathtub: Boundary Crossings at the Public-Private Divide. Geoforum 36, 281-296.

Boardman K (2000) The Ideology of Domesticity: The Regulation of the Household Economy in Victorian Women's Magazines. Victorian Periodicals Review 33, 150-164.

Bowlby S, Gregory S and McKie L (1997) 'Doing home': Patriarchy, Caring, and Space. Women's Studies International Forum 20, 343-350.

Chapman T and Hockey J (1999) 'The Ideal Home as it is Imagined and as it is Lived' in Tony Chapman and Jenny Hockey (eds) Ideal homes? Social Change and Domestic Life Abingdon: Routledge, 1-14.

Cossman B and Fudge J (2002) Privatization, Law, and the Challenge to Feminism. Toronto: University of Toronto Press.

Crompton R and Lyonette C (2008) Who does the Housework? The Division of Labour Within the Home British Social Attitudes: The 24th Report 24, 53-80.

Dalla Costa M and James S (1973) The Power of Women and the Subversion of the Community. London: Falling Wall Press.

Daly HE and Cobb JB (1994) For the Common Good: Redirecting the Economy Toward Community, the Environment, and a Sustainable Future. Boston, Massachussetts: Beacon Press.

Darke J (1994) 'Women and the Meaning of Home' in Rose Gilroy and Roberta Woods (eds) Housing Women Abindgon: Routledge, 11-30.

Davidoff L and Hall C (2013) Family Fortunes: Men and Women of the English Middle Class 17801850. Abingdon: Routledge.

Day K (2000) The Ethic of Care and Women's Experiences of Public Space. Journal of Environmental Psychology 20, 103-124.

Dupuis A and Thorns DC (1998) Home, Home Ownership and the Search for Ontological Security. Sociological Review 46, 24-47.

Everingham C (2002) Engendering Time: Gender Equity and Discourses of Workplace Flexibility. Time \& Society 11, 335-351.

Federici S (1975) Wages Against Housework. London: Falling Wall Press.

Fehlbaum A (2016) 'Cult of Domesticity' in Constance L Shehan (ed), Encyclopedia of Family Studies New York: Wiley Blackwell, 1-4. 
Finch J and Groves D (1983) A Labour of Love: Women, Work, and Caring. Abingdon: Routledge.

Fineman MA (2013) 'Equality, Autonomy and the Vulnerable Subject in Law and Politics' in Martha Fineman and Anna Grear (eds) Vulnerability: Reflections on a New Ethical Foundation for Law and Politics. Farnham: Ashgate, 13-28.

Flynn L and Lawson A (1995) Gender, Sexuality and the Doctrine of Detrimental Reliance. Feminist Legal Studies 3, 105-121.

Folbre N (1991) The Unproductive Housewife: Her Evolution in Nineteenth-Century Economic Thought. Signs: Journal of Women in Culture and Society 16, 463-484.

Francus M (2011) Monstrous Motherhood: Eighteenth-Century Culture and the Ideology of Domesticity. Baltimore: Johns Hopkins University Press.

Freeman E (2011) Time Binds: Queer Temporalities, Queer Histories. Durham, North Carolina: Duke University Press.

Gorman-Murray A (2014) 'Materiality, Masculinity, and the Home: Men and Interior Design' in Andrew Gorman-Murray and Peter Hopkins (eds) Masculinities and Place. Abingdon: Routledge, 209-226.

Grabham E and Beynon-Jones S (2019) 'Introduction' in Sian Beynon-Jones and Emily Grabham (eds) Law and Time. Abingdon: Routledge, 1-28.

Gregson N and Lowe M (1995) Home-Making: On the Spatiality of Daily Social Reproduction in Contemporary Middle-Class Britain. Transactions of the Institute of British Geographers. 224-235.

Gregson N and Lowe M (2005) Servicing the Middle Classes: Class, Gender and Waged Domestic Work in Contemporary Britain. Abingdon: Routledge.

Harris JW (1999) Doctrine, Justice and Home-Sharing Oxford Journal of Legal Studies 19, 421-452.

Himmelweit S (1995) The Discovery of "Unpaid Work": The Social Consequences of the Expansion of "Work". Feminist Economics 1, 1-19.

Hochschild AR (2001) 'Global Care Chains and Emotional Surplus Value' in Will Hutton and Anthony Giddens (eds) On the Edge: Living with Global Capitalism. London: Jonathan Cape, 103-146.

Holloway G (2007) Women and Work in Britain since 1840. Abingdon: Routledge.

Hondagneu-Sotelo P (2007) Doméstica: Immigrant Workers Cleaning and Caring in the Shadows of Affluence, with a New Preface. Berkley and Los Angeles: University of California Press.

Keenan S (2017) Smoke, Curtains and Mirrors: The Production of Race through Time and Title Registration. Law and Critique 28, 87-108.

Locke J (1978) Of Property (from chapter V of Locke's 'Second Treatise of Government' (1689)) in Crawford Brough Macpherson (ed) Property,Mainstream and Critical Positions. Toronto: University of Toronto Press.

Madigan R and Munro M (1991) Gender, House and 'Home': Social Meanings and Domestic Architecture in Britain. Journal of Architectural and Planning Research 8, 116-132.

Madigan R and Munro M (1999) 'The More we are Together: Domestic Space, Gender and

Privacy' in Tony Chapman and Jenny Hockey (eds) Ideal Homes? Social Change and Domestic

Lives. Abingdon: Routledge.

Madigan R, Munro M and Smith SJ (1990) Gender and the Meaning of the Home. International Journal of Urban and Regional Research 14, 625-647.

Mawani R (2014) Law as Temporality: Colonial Politics and Indian settlers. UC Irvine Law Review 4, 65-96.

McKie L, Gregory S and Bowlby S (2002) Shadow Times: The Temporal and Spatial Frameworks and Experiences of Caring and Working. Sociology 36, 897-924.

McRobbie A (2007) Top Girls? Young Women and the Post-Feminist Sexual Contract. Cultural Studies 21, 718-737.

Oakley A (1974) Woman's Work: The Housewife, Past and Present. London: Vintage.

Philipps L (2008) Helping Out in the Family Firm: The Legal Treatment of Unpaid Market Labor. Wisconsin Journal of Law, Gender, \& Society 23, 65-111.

Price J (2002) The Apotheosis of Home and the Maintenance of Spaces of Violence. Hypatia 17, 3970. 
Riach K, Rumens N and Tyler M (2014) Un/doing Chrononormativity: Negotiating Ageing, Gender and Sexuality in Organizational Life. Organization Studies 35, 1677-1698.

Richardson J (2004) Selves, Persons, Individuals: Philosophical Perspectives on Women and Legal Obligations. Aldershot: Ashgate.

Roberts DE (1997) Spiritual and Menial Housework. Yale Journal of Law \& Feminism 9, 51-80.

Rousseau J-J (1979) Emile, or On Education (1762). New York: Basic Books.

Rowthorn R (2002) 'Marriage as a Signal' in Robert Rowthorn and Antony Dnes (eds) Law and Economics of Marriage and Divorce. Cambridge: Cambridge University Press, 132-156.

Saunders P (1984) Beyond Housing Classes: The Sociological Significance of Private Property Rights in Means of Consumption. International Journal of Urban and Regional Research $\mathbf{8}$, 202-227.

Saunders P and Williams P (1988) The Constitution of the Home: Towards a Research Agenda. Housing Studies 3, 81-93.

Silbaugh K (1996) Turning Labor into Love: Housework and the Law. Northwestern University Law Review 91, 1-86.

Sloan B (2015) Keeping up with the Jones Case: Establishing Constructive Trusts in 'Sole Legal Owner' Scenarios. Legal Studies 35, 226-251.

Staples D (2007) No place like Home: Organizing Home-Based Labor in the Era of Structural Adjustment. Abingdon: Routledge.

Thompson F (1982) The Rise of Suburbia. London: Burns \& Oates.

Valverde M (2015) Chronotopes of Law: Jurisdiction, Scale and Governance. Abingdon:Routledge.

Waitt G and Gorman-Murray A (2011) "It's About Time you Came Out": Sexualities, Mobility and Home. Antipode 43, 1380-1403.

West C and Zimmerman DH (1987) Doing Gender. Gender \& Society 1, 125-151.

Williams F (2010) Migration and Care: Themes, Concepts and Challenges. Social Policy and Society 9, 385-396.

Williams JC (1991) Domesticity as the Dangerous Supplement of Liberalism. Journal of Women's History 2, 69-88.

Wong S (2007) Would You 'Care' to Share Your Home? Northern Ireland Legal Quarterly 58, 268286.

Young IM (2005) House and Home: Feminist Variations on a Theme in Iris Marion Young (ed) On Female Body Experience: 'Throwing Like a Girl' and Other Essays. Oxford: Oxford University Press, 123-155. 